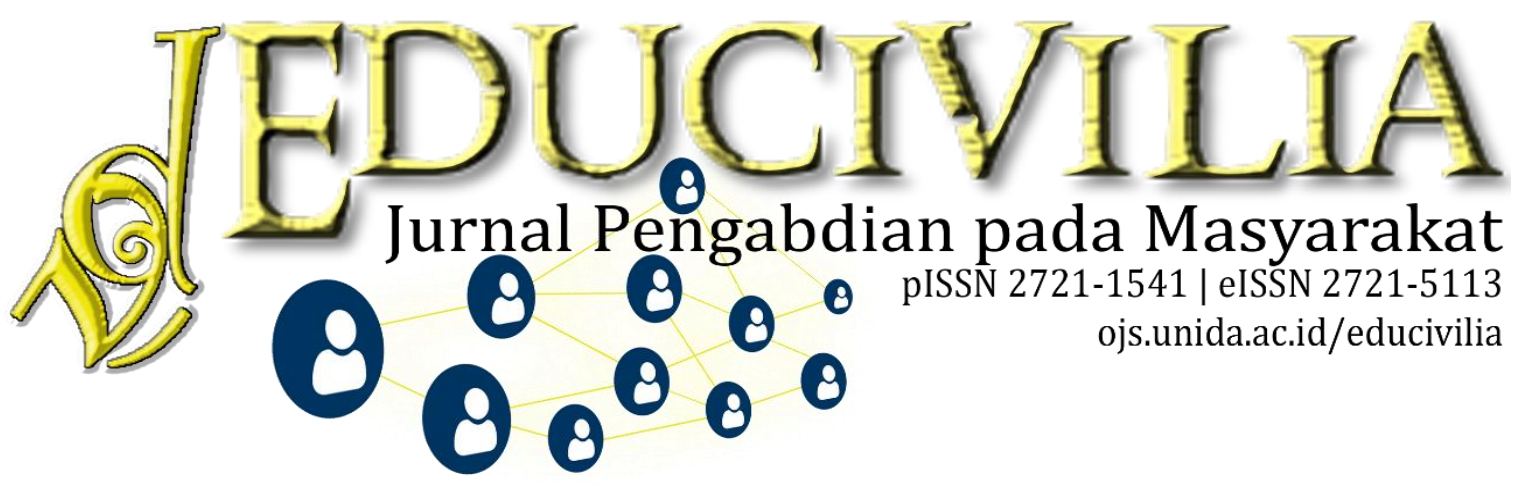

\title{
Pemberian Motivasi Melalui Media Pembelajaran Flashcard Bagi Anak Berkesulitan Belajar (Learning Difficult)
}

\author{
Enny Nurcahyawati ${ }^{1}$, Fitria Iswari ${ }^{2}$, Syahid ${ }^{3}$ \\ 123Universitas Indraprasta PGRI, Indonesia
}

\section{Kilas Artikel \\ Volume 1 Nomor 2 \\ Januari 2021: 31-42 \\ DOI: \\ 10.30997/ejpm.v2i1.2841 \\ Article History \\ Submission: 15-06-2020 \\ Revised: 06-07-2020 \\ Accepted: 18-08-2020 \\ Published: 25-01-2021 \\ Kata Kunci: \\ Kesulitan belajar, Media \\ Pembelajaran Flashcard \\ Keywords: \\ Learning difficulties, \\ Flashcard Learning Media}

Korespondensi:

Syahid syahid@unindra.ac.id

\begin{abstract}
Abstrak
Kegiatan belajar mengajar di sekolah umumnya ditunjukkan hanya kepada siswa yang berkemampuan rata-rata, dan bagi siswa yang punyai kemampuan lebih atau yang berkemampuan kurang biasanya terabaikan. Dan kenyataan yang terjadi didunia pendidikan siswa kategori sangat pandai dan kurang pandai, sedikit mendapat kesempatan yang layak untuk berkembang sesuai dengan kemampuannya. Maka dari sini lah, kemudian timbul apa yang disebut kesulitan belajar (learning difficult). Pembelajaran yang mudah diterima oleh anak berkesulitan belajar adalah dengan menggunakan media pembelajaran. Media belajaran yang efektif dengan menggunakan media flashcard, Karena Media flashcard mempunyai karakteristik yang menyajikan informasi pendek pada setiap kartunya. Misalnya tau dengan mudarah huruf, angka, nama binatang, mengenal buah dan lain sebagainya. Informasi pendek sangat memudahkan siswa mempunyai masalah kesulitan belajar. Metode belajar ini lah yang amat mudah diterapkan, selain mudah tentunya menggembirakan, dan akhirnya mempengaruhi siswa dalam menyerap materi-materi yang disampaikan oleh guru. Seyogya seorang guru harus mempunyai banyak metode yang bervariasi dan menyenangkan dalam memberikan materi setiap mata pelajaran.

Giving motivation through Flashcard Learning Media for Children with Learning Difficulties (Learning Difficult)

Abstract

Teaching and learning activities in schools are generally shown only to students who have average abilities, and for students who have more abilities or who have less abilities are usually ignored. And the reality that happens in the world of education is that the category of students is very clever and less clever, getting a few decent opportunities to develop according to their abilities. So from here lah, then arises what is called learning difficulties (learning difficult). Learning that is easily accepted by children with learning difficulties is to use learning media. Effective learning media using flashcard media, because flashcard media have characteristics that present short information on each card. For example know by mudarah letters, numbers, animal names, recognize fruit and so forth. Short information is very easy for students to have problems learning difficulties. This learning method is very easy to apply, in addition to being easy it is certainly encouraging, and ultimately affects students in absorbing the material
\end{abstract}


PENDAHULUAN

Belajar suatu proses dimana seseorang yang tadinya tidak bisa menjadi bisa dan mengerti segala hal. Pada proses belajar tidak mengenal batas usia dan sampai kapan belajar akan berakhir. Sepanjang hayat dikandung badan, maka seseorang akan terus belajar dan belajar. Tujuan belajar pada hakikatnya mengantarkan siswa menuju metamorfosa intelektual dan moral maupun sosial, agar siswa dapat hidup mandiri di era digital yang komplek dengan banyak masalah didalamnya.

Siswa sekarang banyak yang fokus hanya pada bidang tertentu, sebut saja bidang mengambar sukanya hanya mencoret-coret saja tanpa makna kalau ditanya, aku hanya mengambar, lalu kalau sudah tidak punya ide mereka diam saja. Hal ini banyak banyak kita jumpai pada Siswa TK atau siswa sekolah dasar yang mempunyai kecerdasan biasa-biasa saja bahkan tergolong dibawah rata-rata atau bahkan di atas rata-rata, dan Siswa ini sering disebut siswa berkesulitan belajar.
Dan tentunya sebagai pendidik yang kesehariannya berada di sekolah, tentunya sering sekali menangani peserta didik yang mengalami kesulitan belajar. Peserta didik ini sulit sekali menerima materi dari seorang pendidik. Tidak mustahil seringkali membuat pendidik menjadi kecewa menghadapi peserta didik ini. Tidak hanya pada guru, semua orang tua yang mempunyai anak dengan kesulitan dalam belajar menjadi resah. Harapan yang besar agar anak-anak mereka menjadi anak yang cerdas, memperoleh nilai yang bagus di sekolahnya, akhirnya menjadi sedih karena kenyataan mendapati bahwa nyatanya anak -anak kesulitan dalam belajar.

Pada Kenyataannya seorang anak yang mempunyai masalah kesulitan belajar disetiap sekolah TK atau sekolah dasar, kurang sekali mendapat perhatian dari pemerintah setempat karena Dinas sendiri tidak tahu pasti berapa jumlah anak yang mempunyai kesulitan belajar disetiap sekolah. Dinas setempat tidak mendapat laporan berapa banyak siswa berkesulitan belajar disetiap sekolah yang ada, 
dikarena pihak sekolah kurang mengidentifikasi anak yang mempunyai masalah kesulitan belajar, yang berada dilingkungan sekolahnya, akibatnya mereka tidak mengetahui berapa banyak anak yang berkesulitan belajar.

Permasalah yang berkaitan dengan pentingnya Media Pembelajaran Flash Card dan kelebihan flash card bagi anak berkesulitan belajar di atas dilakukan menggunakan beberapa konsep teori

\section{Media Pembelajaran Flash Card}

Belajar merupakan proses yang sangat kompleks terjadi kepada setiap manusia sepanjang hidupnya. Biasa proses belajar terjadi karena ada interaksi seseorang, dan bisa terjadi dimana saja. Dengan belajar biasanya seseorang akan berhasil ditandai dengan adanya perubahan ilmu pengetahuan yang signifikan pada dirinya. Flash card adalah bentuk media pembelajaran berbentuk grafis berupa kartu kecil biasanya bergambar, terbuat dengan memakai foto, simbol, atau gambar yang ditempelkan pada bagian depan dan pada bagian belakang ada keterangan berupa kata atau kalimat dari gambar Flash card tersebut. Biasanya media pembelajaran Flashcard biasanya mengingatkan atau mengarahkan siswa pada sesuatu yang berhubungan dengan gambar (Angreany \& Saud, 2017). Pada Media kartu (flash card) yang dipakai pada penelitian ini adalah kertas berwarna, ukuran dengan bentuk yang sudah ditentukan. Media kartu ini memiliki banyak kelebihan, diantaranya harga bahan cukup murah, mudah diperoleh di lingkungan sekitar, mudah disusun dan digunakan, mudah dipindahkan karena bahan ringan serta mampu memvisualkan materi yang diinginkan. Selain itu media ini dapat disusun berjajar, dihilangkan atau digandakan sehingga akan merangsang peserta didik untuk aktif belajar dan dapat membantu pemahaman peserta didik (Mulyani, 2017). Media flash card salah satu bentuk media edukatif berbentuk kartu yang memuat gambar dan kata dengan ukuran disesuaikan dengan para siswa yang dihadapi juga untuk mendapatkannya bisa membuat sendiri atau menggunakan yang sudah jadi. Media flashcard ini adalah media pembelajaran yang dapat membantu dalam meningkatkan berbagai aspek seperti : mengembangkan daya ingat, 
melatih kemandirian dan meningkatkan keterampilan siswa (Hotimah, 2010).

\section{Kelebihan Media Flashcard}

Media flash card digolongkan kedalam media visual (gambar), media flash card ini memiliki banyak kelebihan, sebagaimana yang diungkapkan oleh Susilana dan Riyana (2009 : 94) dalam Hotimah (2010) antara lain:

a) Sangat mudah dibawa kemanamana; karena ukuran yang kecil maka flash card dapat disimpan di tas bahkan di saku, tidak membutuhkan ruang yang besar, dapat dengan mudah digunakan di manapun, di kelas ataupun di luar kelas.

b) Praktis; pembuatannya serta penggunaannya, dalam menggunakan media flash card guru tidak perlu memiliki keahlian khusus, media ini tidak memerlukan listrik. menggunakannya tinggal menyusun urutan gambar sesuai dengan keinginan kita, dan dipastikan posisi gambar tepat tidak terbalik, dan jika sudah dipakai tinggal disimpan dengan cara diikat atau memakai kotak khusus supaya tidak tercecer. c) Mudah diingat; karena kombinasi antara gambar dan teks cukup memudahkan siswa untuk mengenali konsep sesuatu, untuk mengetahui nama sebuah benda dapat dibantu dengan gambarnya, begitu juga sebaliknya untuk mengetahui nama sebuah benda atau konsep dengan melihat hurufnya atau teksnya.

d) Menyenangkan; media flash card dalam penggunaannya dapat melalui permainan. Misalnya siswa secara berlomba-lomba mencari suatu benda atau nama-nama tertentu dari flashcard yang disimpan secara acak, dengan cara berlari siswa berlomba untuk mencari sesuatu perintah.

\section{Siswa Berkesulitan Belajar}

Menurut Yusuf (Yusuf, 2003) Siswa yang berkesulitan belajar merupakan peserta didik yang mengalami kesulitan dalam tugas akademik yang khusus maupun yang umum, disebabkan dengan adanya disfungsi neurologis, proses psikologis dasar maupun penyebab lainnya sehingga prestasi belajarnya rendah dan akhirnya anak beresiko tidak naik kelas. Ada 3 pembagian tingkat Kesulitan belajar 
secara spesifik yaitu (1) Kesulitan belajar membaca (disleksia), (2) kesulitan belajar berhitung (diskalkulia),dan (3) kesulitan belajar menulis (disgrafia). Kesulitan belajar adalah kondisi yang dapat dialami oleh semua siswa-siswi.

Kesulitan belajar akan bertambah parah manakala semua guru belum memahami bentuk-bentuk dari kesulitan belajar serta bagaimana caranya menangani secara tepat masalah learning difficult yang dialami para siswanya. Akibat dari masalah kesulitan belajar yang terjadi adalah tersendatnya proses belajar dari siswa itu sendiri. Tidak jarang ada siswa yang tinggal kelas dan harus mengulang karena masalah kesulitan belajar. Salah satu bentuk masalah sulit belajar yang berkaitan dengan akademik adalah kesulitan belajar membaca. Kesulitan belajar membaca ini merupakan kesulitan belajar yang paling banyak ditemukan pada siswa-siswa Taman Kanak-kanak dan sekolah dasar pada tingkat 1 sampai dengan tingkat 3

Kesulitan belajar dapat ditanggulangi dengan menggunakan media pembelajaran. Media pembelajaran yang menyenangkan dan tidak menjenuhkan bagi siswa TK dan
SD tetapi sangat menyenangkan. Media pembelajaran dapat meningkatkan proses belajar para siswa dan diharapkan mendapat hasil yang maksimal. Menurut Nana Sudjana dan Ahmad Rivai (Sudjana \& Rivai, 2015) alasan memanfaatkan media pembelajaran bagi siswa adalah (1) Pengajaran akan jauh lebih menarik, akan dapat membangun motivasi belajar, (2) Materi pengajaran lebih jelas sehingga mudah dipahami oleh semua siswa sehingga siswa dapat menguasai tujuan belajar, (3) Metode mengajar lebih bervasiasi, tidak hanya sematamata komunikasi verbal tetapi guru tidak kehabisan tenaga dan akan jauh lebih banyak melihat ineraksi para siswanya dan, (4) Siswa akan lebih banyak melakukan semua kegiatan belajar dengan mengamati dan melakukan serta mendemostrasikannya.

Di Era milenial menuntut semua guru mampu membuat pembelajaran yang kreatif. Model pembelajaran yang kreatif bervariasi bentuknya dan dapat disesuaikan dengan kebutuhan para siswa. Karena membawa siswa masuk ke dalam materi ajar secara inovatif dan menyenangkan. Pembelajaran bermedia flashcard dinilai mampu 
membangkitkan rasa keingintahuan siswa memperhatikan semua materi ajar. Terlebih lagi flashcard yang digunakan berwarna terang dan bergambar menarik dan sangat mudah digunakan serta menyenangkan.

\section{METODE}

\section{Tahapan dan Lokasi Pengabdian}

Pada kegiatan pelatihan ini terdiri dari beberapa 5 tahapan.

1. Tahap Komunikasi

2. Tahap pengumpulan data observasi

3. Tahap persiapan kegiatan

4. Tahap pelaksanaan kegiatan.

5. Tahap Penyusunan laporan

Program pengabdian masyarakat ini dilaksanakan di TKIT NAMIRA Tajur Halang dengan melibatkan kepala sekolah beserta guru-guru, bahkan anak-anak yang berkesulitan belajar juga ikut serta.

\section{Variable yang diukur}

Variable yang diukur yaitu kemampuan semua peserta program pengabdian masyarakat untuk membuat Alat Permainan Edukasi (APE) sendiri, khusunya dari barangbarang yang mudah di dapatkan pada lingkungan peserta. Kreativitas para peserta menjadi tolok ukur keberhasilan pengabdian ini. Peserta melakukan kerjasama dalam Tim. Dan tentunya, kemampuan berkoordinasi pun menjadi salah satu aspek keberhasilan yang membuat bentuk APE menjadi tambah bervariasi.

\section{Teknik Pengumpulan dan Analisa Data}

Kegiatan pelatihan ini terdiri dari beberapa tahapan yaitu 1). Tahap Komunikasi 2). Tahap pengumpulan data observasi, 3). Tahap persiapan kegiatan, 4). Tahap pelaksanaan kegiatan, dan 5). Tahap Penyusunan laporan

\section{Tahap Analisa}

Tahap analisa dilakukan di TKIT Namira di Tajur halang Bogor. Tim dari Fakultas Desain Komunikasi Visual bersinergi dengan semua Tim pengabdian untuk menganalisa kebutuhan dari guru-guru Taman Kanak-kanak Islam Terpadu. Tim pengabdian mengkhususkan untuk memetakan kebutuhan para guru Taman Kanak-kanak Islam Terpadu terkait kemampuan mengajarkan pengenal macam-macam nama hewan dan huruf. Sebelumnya, untuk dapat melakukan tahap analisa, ada serangkaian langkah yang dilakukan. 
Tim mengamati dari segi apa yang dapat ditingkatkan. Hal ini dilakukan ketika rapat persiapan pengabdian yang dilakukan oleh tim dan juga beberapa tim lain dengan pihak fakultas. Tim juga melakukan pembuatan proposal pengabdian. Setelah itu, tim dari fakultas melaksanakan rapat persiapan pengabdian di TKIT Namira di Tajur halang Bogor. Setelah dilaksanakan persiapan dan survey oleh Tim pendahulu dari pihak fakultas, tim melakukan rapat tentang strategi pengabdian yang tepat guna dengan kebutuhan para TKIT Namira tersebut

\section{Tahap Perancangan dan Pengembangan Konten}

Setelah tahapan analisa kebutuhan peserta didik selesai dilakukan, Tim berdiskusi terkait rancangan pelatihan pembuatan Flash Card dan hasil survey yang tepat untuk dilaksanakan di daerah Tajur Halang Bogor. Tim juga melakukan perencanaan terkait Alat Permainan Edukatif (APE) untuk pelatihan pembuatan Flash Card. Konten yang diajarkan membuat dan menggunakan kartu kata sebagai APE.

\section{Tahap Pelaksanaan}

Pada Tahapan pelaksanaan pengabdian ini dilakukan bersama Tim pengabdian dengan tema beragam. Untuk Tim pengabdian sendiri fokus untuk melakukan pelatihan menggunakan APE dari media yang tersedia di lingkungan. Tim pengabdian kemudian memaparkan tentang APE dan manfaat dan materi lainnya. Kemudian diberikan bahan kertas yang sudah dipotong, beserta lem untuk membuat APE yang disebar oleh para Tim pengabdian. Bahan tersebut kemudian dibentuk menjadi media flash cards. Di samping itu, Tim melakukan pendampingan terhadap para guru Taman Kanak-kanak Islam Terpadu tersebut agar terjadi sinergitas. Untuk menunjukkan hasil dari pengabdian dalam khalayak penggiat ilmu, maka dilakukankan pembuatan jurnal dan publikasi ilmiah.

\section{HASIL \& PEMBAHASAN}

Media pembelajaran flash card adalah media yang berbentuk kartu bergambar, di sisi pertama bisa hurup atau angka dan di sisi keduanya adalah gambar atau keterangan lainnya yang berukuran 10,5 x 14,8 cm. Setiap kartu bisa menggunakan gambar yang dibuat tangan atau photo-photo bahkan 
dengan memanfaatkan gambar-gambar yang ada, lalu gambar dan photo tadi ditempel pada lembaran-lembaran flashcard. Gambar atau photo yang ada di flashcard adalah sebuah rangkaian pesan yang disajikan, dengan keterangan disetiap gambar yang dicantumkan pada sisi belakang kartu tersebut. Pada media pembelajaran flashcard cocok pada kelompok kecil saja, agar lebih efektif pembelajaran tersebut.

Keterkaitan media pembelajaran dengan teori belajar (Syah, 2009) menunjukkan bahwa:

a) Flashcard dapat memberikan umpan balik yang positif bagi siswa. Dan apabila dilaksanakan beraturan akan memberikan dorongan belajar siswa;

b) latihan dan pengulangan akan diingat dalam jangka waktu yang lama pada ingatan siswa;

c) Penerapan akan hasil belajar yang telah dikuasai oleh siswa dengan baik akan ditransfer pada suatu permasalahan atau kondisi baru.

Sejalan dengan Muhibbin, Levie dan Lentz dalam Arsyad (Arsyad, 1997) menyebutkan adanya empat macam fungsi media pembelajaran secara visual. Berikut ini adalah empat fungsi yang dimaksud:

\section{A.Fungsi Atensi flashcard berfungsi} untuk menarik dan mengarahkan semua perhatian siswa untuk lebih berkonsentrasi pada isi pelajaran yang berkaitan.

B. Fungsi Afektif flashcard mampu menunjukkan tingkat kenikmatan/ kesenangan siswa paa saat belajar atau membaca teks. Hal ini disebabkan karena simbol atau lambang yang dapat membangkitkan emosi dan sikap siswa.

C. Fungsi Kognitif flashcard membantu memperlancar pencapaian tujuan guna memahami dan mengingat akan informasi atau pesan yang ada dalam suatu teks.

D. Fungsi Kompensatoris. flashcard berfungsi untuk membantu seorang siswa yang lemah dan lambat dalam menerima atau memahami isi pelajaran yang disajikan dengan teks atau secara verbal

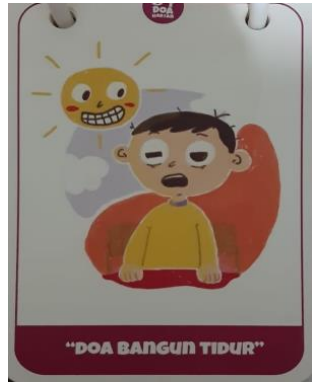

Sisi Pertama

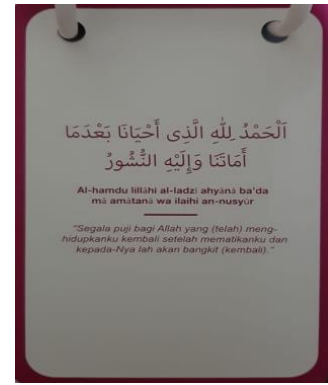

Sisi Kedua 
Dalam pelaksanaan dilapangan tentukan disajikan juga bagaimana tatacara pembuatan media pembelajaran flash card yang mudah;

Pertama. Siapkan kertas karton, kertas ini berfungsi untuk menggambar atau menyimpang dan menempel gambar atau photo yang sesuai dengan tujuan pebelajaran.

Kedua. Ukur kertas dengan menggunakan penggaris dengan ukuran $10,5 \times 14,8 \mathrm{~cm}$.

Ketiga. Potong kertas dengan menggunakan sebuah gunting sesuai dengan ukuran yang kita sudah ukur tadi.

Keempat. Jika objek gambar akan langsung dibuat dengan tangan pada kertas yang sudah dipotong tadi, atau membuat pola terlebih dahulu.

Kelima. Mulailah menggambar/ melukis dengan menggunakan kuas, pinsil berwarna, atau membuat sebuah desain dengan ukuran yang sesuai, kalau menggunakan pola kemudian tempelkan pola tersebut pada alas yang sudah dipotong-potong tadi

Keenam. Jika gambar yang akan ditempel memanfaatkan gambar yang sudah dijual ditoko-toko, maka selanjutnya gambar-gambar tersebut tinggal dipotong sesuai dengan ukuran kemudian ditempel menggunakan alat perekat lem kertas.

Ketujuh. Terakhir, berilah tulisan pada bagian kartu-kartu tersebut sesuai dengan nama objek pada gambar. Misalnya dengan menggunakan bahasa Indonesia dan Inggris atau arab dan lain-lainnya.

Guna meningkatkan kemampuan anak berkesulitan belajar, maka penggunaan media pembelajaran flashcard sangat efektif karena dapat meningkatkan keingintahuannya dan kemampuannya untuk berinteraksi. Menurut Jhonson dan Jhonson (1984:10) dalam Mulyono (Abdurrahman, 2003) ada empat bagian dasar pembelajaran (1) Saling ketergantungan yang positif, (2) Interaksi dengan tatap muka, (3) Akuntabilitas/ pertanggungjawaban individu, dan (4) Keterampilan menjalin hubungan. Dalam interaksi yang aktif antara guru dan siswa berkesulitan belajar, guru haruslah menciptakan suasana belajar yang mendorong anakanak untuk saling membutuhkan.

Pada pelaksanaan penggunaan media pembelajaran flashcard antara guru dan siswa berkesulitan belajar, ada 
beberapa yang harus dilakukan antara lain

Mempersiapkan diri sendiri. Guru harus menguasai bahan pembelajaran dengan baik dan memiliki keterampilan menggunakan media flash card. Dan bila memungkinkan melakukan latihan berkali-kali. Dan periksa urutan gambar agar tidak ada yang terlewat.

- Mempersiapkan flash card, sebelum memulai pembelajaran dipastikan bahwa jumlahnya cukup, periksa juga urutannya apakah sudah benar

- Mempersiapkan tempat pembelajaran, kaitannya dengan posisi seorang guru sebagai pemberi pesan pembelajaran. Apakah guru sudah ada ditengah para siswa lalu apakah ruangan belajar sudah tersusun dengan baik kemudian apakah intensitas pencahayaan di ruangan tersebut sudah baik, karena yang harus diperhatikan bahwa para siswa harus dapat melihat flash card dengan jelas dari semua arah.

- Mempersiapkan para siswa, bagaimana cara duduk para siswa ditata dengan baik, misalnya melingkar dihadapan guru. Lalu perhatikan apakah ada diantara siswa yang pandangannya terhalang oleh teman yang lainnya harus benarbenar diyakini bahwa pandangan siswa harus jelas pada sajan guru yang ada dihadapan mereka

Disetiap pelaksanaan media pembelajaran pasti ada manfaat yang diambil. Pada penggunaan media pembelajaran flash card khusus untuk anak berkesulitan belajar, kami melihat ada beberapa kelebihan dari media pembelajaran tersebut, diantaranya Menyenangkan, (2) Mudah diingat, (3) Praktis, (4) Mudah dibawa, Meningkatkan prestasi belajarnya, (6) mendorong tumbuhnya motivasi belajar.

Perlu dipahami bahwa perlakuan terhadap anak-anak berkesulitan belajar mengharuskan guru sebagai demonstrator dapat menunjukkan kepada siswa segala sesuatu yang dapat membuat siswa lebih mengerti dan memahami pada setiap pesan yang disampaikan. Juga dengan dukungan lingkungan keluarga yang sangat baik akan mempercepat perkembangan kematangan motivasi belajarnya, sehingga ketidakmampuan belajar dapat dipahami sebagai proses yang belum matang pada seorang anak berkesulitan belajar. 


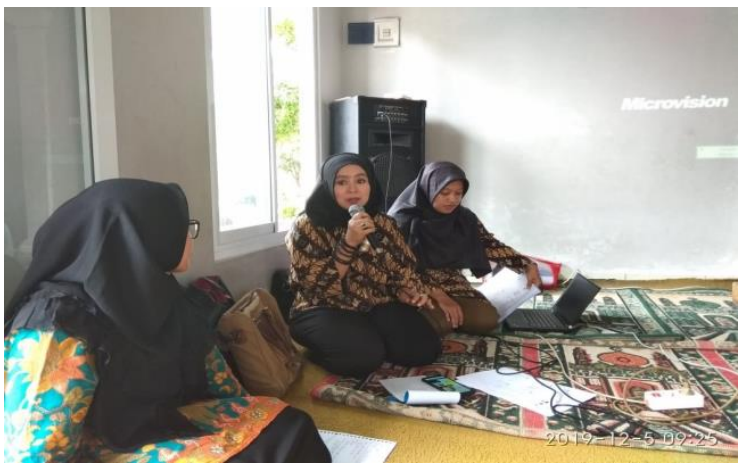

Gambar 1: Pembukaan Tim ABDIMAS

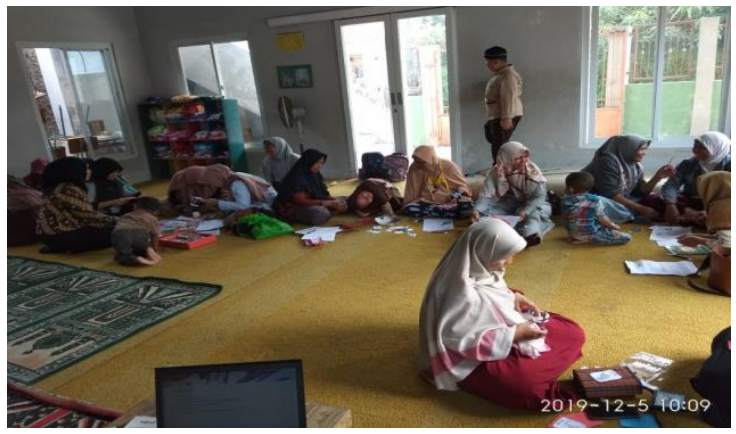

Gambar 2: Praktek Pembuatan FC

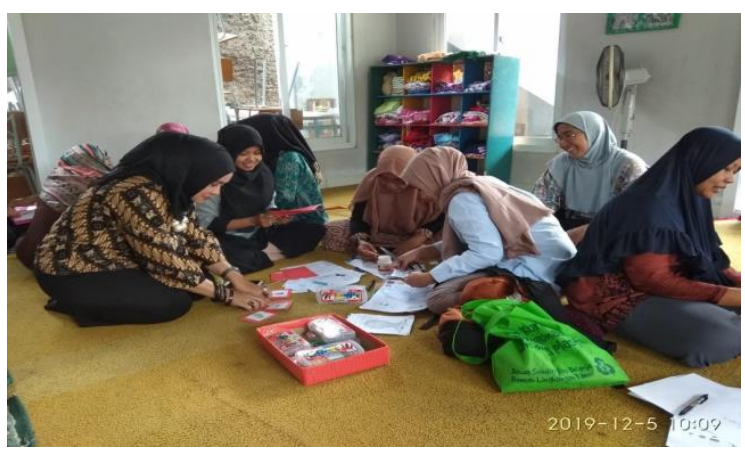

Gambar 3: Tim Dosen menjadi Fasilitator pembuatan FC

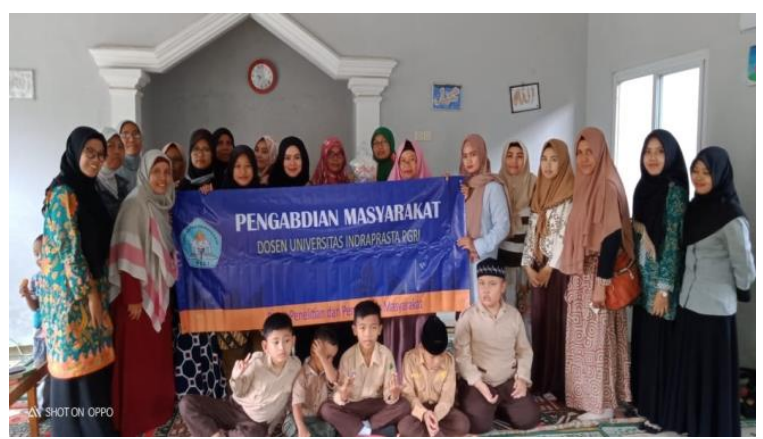

Gambar 4: Tim dan Peserta Pelatihan Pembuatan Flash Card TKIT Namira

\section{SIMPULAN}

Dari hasil pembahasan tersebut perlu ditekankan bahwa peran dan tugas guru dalam proses pembelajaran terhadap anak berkesulitan belajar adalah;

1) Sebagai pengelola proses pembelajaran

2) sebagai pembimbing proses pembelajaran

3) sebagai motivator proses pembelajaran

Kemudian, pada pengembangan media pembelajaran flashcard sangatlah efektif digunakan dalam pembelajaran anak berkesulitan belajar. Media pembelajaran flashcard merupakan media pembelajaran yang menarik, Metode kartu cepat/flashcard dapat meningkatan kemampuan belajar, dapat melatih kemampuan dan keinginan untuk mengenali sesuatu yang tertera pada kartu-kartu tersebut, dapat melatih kemampuannya mendengar dan menulis dan dapat menciptakan kesenangan bagi anak berkesulitan belajar.

\section{UCAPAN TERIMA KASIH}

Ucapan terima kasih kami ucapkan kepada Kepala Pusat Pengabdian kepada Masyarakat, LPPM Universitas 
Indraprasta PGRI dan Ketua Pengelola

TKIT Namira yang telah membantu terlaksanakannya kegiatan pengabdian masyarakat ini.

\section{DAFTAR PUSTAKA}

Abdurrahman, M. (2003). Pendidikan bagi anak berkesulitan belajar. Jakarta: Rineka Cipta.

Angreany, F., \& Saud, S. (2017). KEEFEKTIFAN MEDIA PEMBELAJARAN FLASHCARD DALAM KETERAMPILAN MENULIS KARANGAN SEDERHANA BAHASA JERMAN SISWA KELAS XI IPA SMA NEGERI 9 MAKASSAR. Eralingua: Jurnal Pendidikan Bahasa Asing dan Sastra, 1 No. 2 Agustus, 139-149. Retrieved Februari 26, 2020, from https://ojs.unm.ac.id/eralingua/ar ticle/view/4410/2549

Arsyad, A. (1997). Media Pembelajaran. Jakarta: Raja Grafindo Persada.

Hotimah, E. (2010). PENGGUNAAN MEDIA FLASHCARD DALAM MENINGKATKAN KEMAMPUAN SISWA PADA PEMBELAJARAN KOSAKATA BAHASA INGGRIS KELAS II MI AR-ROCHMAN SAMARANG GARUT. Jurnal Pendidikan Universitas Garut, Vol. 04; No. 01; 2010, 10-18. doi:ISSN: 1907$932 X$

Mulyani, S. (2017). Penggunaan Media Kartu (Flash Card) dalam Meningkatkan Hasil Belajar Konsep Mutasi bagi Peserta Didik Kelas XII. Jurnal Profesi Keguruan, JPK 3 (2) (2017), 143-148. Retrieved February 26, 2020, from https://journal.unnes.ac.id/nju/in dex.php/jpk/article/view/10786/7 091

Mulyasa, H. E. (2011). Praktik Penelitian Tindakan Kelas. Bandung: PT Remaja Rosdakarya.
Sudjana, N., \& Rivai, A. (2015). Media Pengajaran. Bandung: Sinar Baru Algensindo.

Syah, M. (2009). Psikologi Belajar. Jakarta: Raja Grafindo Persada.

Trianto. (2011). Panduan lengkap penelitian tindakan kelas: teori dan praktik. Jakarta: Prestasi Pustakarya.

Yusuf. (2003). Motivasi dalam Belajar. Jakarta: P2LPTK. 